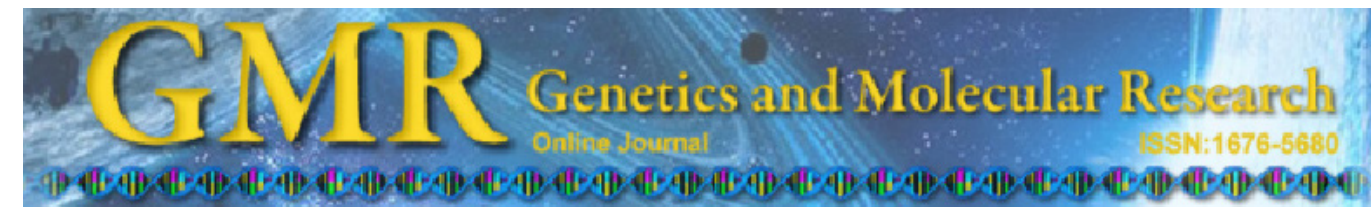

Methodology

\title{
Snap bean recommendation based on different methods of phenotypic stability
}

\author{
C.D. Marinho, G.A. Gravina, L.C. Araújo, S.N.C. Almeida, \\ A.T. Amaral Júnior, R.F. Daher and L.S.A. Gonçalves \\ Universidade Estadual do Norte Fluminense Darcy Ribeiro, \\ Campos dos Goytacazes, RJ, Brasil \\ Corresponding author: C.D. Marinho \\ E-mail: caillet.marinho@yahoo.com.br
}

Genet. Mol. Res. 12 (1): 248-255 (2013)

Received April 23, 2012

Accepted October 7, 2012

Published January 30, 2013

DOI http://dx.doi.org/10.4238/2013.January.30.11

\begin{abstract}
In order to recommend the best strains of snap beans from the Universidade Estadual do Norte Fluminense (UENF) breeding program, different methods of analysis of phenotypic stability were adopted to evaluate the performance of 14 lines $\left(\mathrm{F}_{9}\right.$ and $\left.\mathrm{F}_{10}\right)$ of indeterminate growth habit, which were compared with 3 controls, namely, 2 commercial varieties (Feltrin and Top Seed Blue Line) and 1 parent (UENF-1445). The experiments were conducted in Bom Jesus do Itabapoana in 2010 and 2011, and in Cambuci in 2011. The experiment was arranged in a randomized block design with 4 replications. To complement the information obtained by different methods, the UENF 7-5-1 strain was indicated for favorable environments (Bom Jesus do Itabapoana; 2010 and 2011), UENF 7-10-1, UENF 7-14-1, and UENF 7-20-1 strains were indicated for an unfavorable environment (Cambuci), and UENF 7-12-1 was indicated for both.
\end{abstract}

Key words: Phaseolus vulgaris L.; Breeding of snap beans; Genotype $\mathrm{x}$ environment interaction 


\section{INTRODUCTION}

Agriculture in Northwestern Rio de Janeiro is primarily based on sugar cane and coffee crops (Souza et al., 2009). Instituto Brasileiro de Geografia e Estatística (IBGE, 2010) data show that these crops covered $60 \%$ of the cropland in this region in 2010 , while rice, beans and maize crops covered $33 \%$. Therefore, 5 crops alone covered $93 \%$ of the planted area in the Northwestern Rio de Janeiro in 2010. Thus, the agricultural sector in this region is very fragile and has little flexibility, which has contributed to its decline and the subsequent exodus of the rural population.

In this scenario, new alternatives for the diversification of crops are necessary to improve the socioeconomic conditions of people in this sector. These alternatives include horticulture, which is considered to be an excellent choice. Snap beans are among the crops with significant economic value; this crop is little known in Northwestern Rio de Janeiro and is commonly cultivated in the mountainous region of the state. Its culture can provide additional income for rural individuals and allows producers to control the production of the seeds they require.

Therefore, since 2004, the Universidade Estadual do Norte Fluminense Darcy Ribeiro (UENF) has maintained a breeding program using snap beans with indeterminate growth habit, aiming to select high yielding genotypes with commercial quality for Northern and Northwestern Rio de Janeiro.

For the commercial selection of superior genotypes, it is necessary to consider the joint action of genotypes and environments and the interaction between genotype and environment (Allard, 1971; Fehr, 1987; Falconer and Mackay, 1996). Genotype x environment interaction (GE) can make it difficult to identify the best individuals, since in instances of complex interactions, certain genotypes may be superior in a certain environment, but not in others (Cruz and Regazzi, 2001).

Thus, GE interaction causes deviations in phenotypic stability, whose estimate can be achieved by various techniques (Farias et al., 1997; Borges et al., 2000; Mauro et al., 2000; Prado et al., 2001; Rosse et al., 2002; Murakami et al., 2004; Backes et al., 2005; Silva and Duarte, 2006; Cargnelutti Filho et al., 2007; Scapim et al., 2010; Vilela et al., 2011) that can be used separately or in combination.

The indication of genotypes for particular environments is an unambiguous, important action for applied breeding and that different techniques for estimating stability may provide different recommendations for producers. Therefore, the present study was developed to evaluate the yield stability of 14 strains of snap beans from the UENF breeding program, based on different methods of phenotypic stability, to ensure reliable recommendation of new cultivars for Northwestern Rio de Janeiro.

\section{MATERIAL AND METHODS}

We evaluated 14 strains $\left(\mathrm{F}_{9}\right.$ and $\left.\mathrm{F}_{10}\right)$ of snap bean pods with indeterminate growth habit and 3 controls, consisting of 2 commercial varieties (Feltrin and Top Seed Blue Line) and 1 parent (UENF-1445). The experiments were conducted in 2010 (Bom Jesus do Itabapoana) and 2011 (in the cities of Bom Jesus do Itabapoana and Cambuci), totaling 3 environments that represent Northwestern Rio de Janeiro. 
The experiment was arranged in a randomized block design, with 4 replications. The experimental plot consisted of 10 plants, spaced $1.0 \times 0.5 \mathrm{~m}$ apart and the analyses were performed based on the 8 central plants in the row. The 2 plants at the ends of the row were maintained for seed production.

Individual variance analyses were carried out and were followed by a joint variance analysis, according to the statistical model proposed by Hallauer and Miranda Filho (1986). The sources of variation were considered random, with the exception of the genotypes.

The methods of Yates and Cochran (1938), Plaisted and Peterson (1959), Kang and Phan (1991), Lin and Binns (1988), and those modified by Carneiro (1998) were used to estimate the stability parameters for pod yield (PY).

To verify the agreements and/or disagreements among estimates of the stability parameters, we utilized the Spearman rank correlation coefficient $(\rho)$ given by the expression

$$
\rho=1-\frac{6 \sum_{i=1}^{n} d_{i}^{2}}{n\left(n^{2}-1\right)},
$$

in which $\rho$ is the Spearman correlation coefficient, $d_{i}$ is the difference between the orders and $n$ is the number of pairs of orders.

The analyses and estimates of the parameters were performed using the GENES software system (Cruz, 2006) and the Microsoft Office Excel 2010 application (Microsoft, Redmond, WA, USA).

\section{RESULTS AND DISCUSSION}

Variability was observed among the strains, as there was a significant difference for the genotype source of variation $(\mathrm{P}<0.01)$. There was also a significant effect for environments $(\mathrm{P}<0.05)$ and GE interaction $(\mathrm{P}<0.05)$, which explains the detailed study on phenotypic stability of genotypes (Table 1 ).

\begin{tabular}{|c|c|c|}
\hline \multirow[t]{2}{*}{$\mathrm{CV}$} & d.f. & Average square \\
\hline & & PY \\
\hline Block/Environment & 9 & 182.87 \\
\hline Genotypes (G) & 16 & $126.50 * *$ \\
\hline Environment (E) & 2 & $1432.82 *$ \\
\hline $\mathrm{G} \times \mathrm{E}$ & 32 & $43.49^{*}$ \\
\hline Residue & 144 & 27.24 \\
\hline Average & & 33.13 \\
\hline CVe (\%) & & 15.76 \\
\hline $\mathrm{QMr}^{+} / \mathrm{QMr}^{-}$ & & 1.58 \\
\hline Superior limit & & 38.69 \\
\hline Inferior limit & & 27.36 \\
\hline \multicolumn{3}{|l|}{ Controls } \\
\hline Top seed blue line & & 32.16 \\
\hline Feltrin & & 32.14 \\
\hline UENF-1445 & & 34.72 \\
\hline
\end{tabular}

$\mathrm{CV}=$ coefficients of variations; d.f. $=$ degrees of freedom. $* \mathrm{P}<0.01 . * * \mathrm{P}<0.05$. 
The experimental coefficient of variation (CVe) was $15.76 \%$, which is below the acceptable limit set by the Ministry of Agriculture, Livestock and Supply for the performance of tests to determine the value for cultivation and use for bean plants, which determines the CVe maximum value of $25 \%$ (Brasil, 2012). This indicates adequate accuracy in the performance of our experiments (Table 1).

The overall joint average for PY was $33.13 \mathrm{t} / \mathrm{ha}$, an estimate higher than that of the commercial controls from the Feltrin (32.14 t/ha) and Top Seed Blue Line (32.16 t/ha). Considering that the average yield of beans in the State of Rio de Janeiro, according to the Empresa de Assistência Técnica e Extensão Rural (EMATER - RJ; Technical Assistance and Rural Extension Company) is $22.5 \mathrm{t} / \mathrm{ha}$, the productive potential of the genotypes tested was highly significant. The highest limit for PY (38.69 t/ha) was obtained in the UENF 7-10-1 strain, and the lowest was obtained in the UENF 14-6-3 strain (Table 1).

The Spearman coefficient $(\rho)$ demonstrated that the methods of Yates and Cochran (1938) and of Plaisted and Peterson (1959) showed no significant correlation with the PY. The others provided a positive and significant $(\mathrm{P}<0.01)$ correlation with $\mathrm{PY}$. The methods of Lin and Binns (1988) and the modification made by Carneiro (1998) resulted in the best correlations with PY, showing correlations of $0.98,0.94$ and 0.88 for general stability index (Pi), favorable Pi and unfavorable Pi, respectively. The weighting method of Kang and Phan (1991) also proved to be effective in relating the estimates of stability with PY (Table 2).

The methods of Yates and Cochran (1938) and of Plaisted and Peterson (1959) showed no significant correlation with any method, although significant correlations were obtained after their weightings were performed according to the method of Kang and Phan (1991). Moreover, after weighting, these methods began to show significant positive correlations with the methods of Lin and Binns (1988) and the modification proposed by Carneiro (1998). The traditional weighted method (1938) presented higher weighted correlation $(\rho=0.8652)$ with the unfavorable Pi, while the method of Plaisted and Peterson (1959) presented higher correlation $(\rho=0.7059)$ with favorable Pi. This finding highlights the importance of the method of Kang and Phan (1991) to generate refined data on the methods of phenotypic stability based on the analysis of variance (ANOVA).

Table 3 shows that complementary information for the Plaisted and Peterson (1959) method can be achieved by the Lin and Binns (1988) method, as the former method estimated the UENF 7-10-1 strain to be the most unstable, while the latter method described this strain to be the most stable, with genetic percentage for interaction of only $36.72 \%$. Complementation of results was also observed between the Yates and Cochran (1938) method and unfavorable Pi. The first indicated, in the first 4 positions, the UENF 7-10-9, UENF 7-3-1, UENF 7-14-1, and UENF 7-20-1 strains as the most stable and, the second method the UENF 7-10-1, UENF 7-14-1 and UENF 7-20-1 strains were indicated in the 3 first positions. Therefore, it is possible to conclude that, in the present study, the Yates and Cochran method (1938) achieved higher association, with indication for unfavorable environments. A similar conclusion was previously described by Cargnelutti Filho et al. (2007).

The method of Yates and Cochran (1938) indicated that the UENF 7-10-1 strain is the most stable. It presented the highest PY average, considering the 3 environments (38.69 t/ ha), in opposition to the situations typically encountered in the literature when the traditional method is used, in which the genotypes with regular behavior among the environments are generally less productive (Cruz and Regazzi, 2001). This can be corrected, as shown in the 
C.D. Marinho et al.

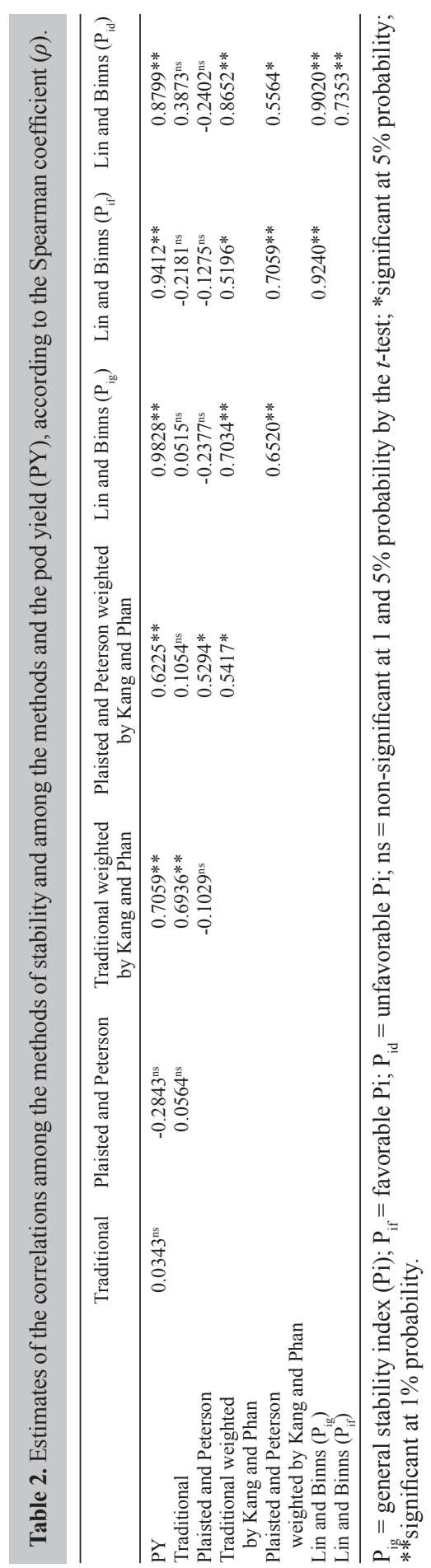




\begin{tabular}{|c|c|c|c|c|c|c|c|}
\hline Ranking & $\mathrm{Y} \& \mathrm{C}$ & $\mathrm{P} \& \mathrm{P}$ & $\mathrm{K} \& \mathrm{P} / \mathrm{Y} \& \mathrm{C}$ & $\mathrm{K} \& \mathrm{P} / \mathrm{P} \& \mathrm{P}$ & L\&B & $P_{\text {if }}$ & $P_{i d}$ \\
\hline 1st & UENF 7-10-1 & UENF 9-24-12 & UENF 7-10-1 & UENF 7-12-1 & UENF 7-10-1 & UENF 7-6-1 & UENF 7-10-1 \\
\hline 2 nd & UENF 7-3-1 & UENF 7-12-1 & UENF $7-20-1$ & UENF 7-5-1 & UENF 7-6-1 & UENF 7-5-1 & UENF 7-14-1 \\
\hline $3 r d$ & UENF 7-14-1 & UENF 7-4-1 & UENF 7-14-1 & UENF 7-20-1 & UENF 7-5-1 & UENF 14-3-3 & UENF 7-20-1 \\
\hline 4th & UENF 7-20-1 & UENF 14-6-3 & UENF 7-12-1 & UENF 9-24-12 & UENF 7-20-1 & UENF 7-12-1 & UENF 7-12-1 \\
\hline 5 th & UENF 15-23-4 & UENF 7-5-1 & UENF 7-3-1 & UENF 14-3-3 & UENF 7-12-1 & UENF 7-20-1 & UENF 7-5-1 \\
\hline 6th & UENF 9-24-12 & UENF 7-20-1 & UENF 7-5-1 & UENF 7-6-1 & UENF 7-14-1 & UENF $7-10-1$ & UENF 7-6-1 \\
\hline 7th & Top seed & UENF 7-3-1 & Top Seed & UENF 7-14-1 & UENF 14-3-3 & Progenitor & UENF 7-9-1 \\
\hline 8th & UENF 7-12-1 & UENF 14-4-3 & UENF 7-6-1 & UENF 7-4-1 & UENF 7-9-1 & UENF 7-14-1 & UENF 7-3-1 \\
\hline 9 th & UENF 7-4-1 & UENF 14-3-3 & UENF 9-24-12 & UENF 7-10-1 & Parent & UENF 7-9-1 & Parent \\
\hline 10th & UENF 14-6-3 & UENF 7-14-1 & UENF 15-23-4 & UENF 7-3-1 & Feltrin & Feltrin & UENF 14-3-3 \\
\hline 11 th & UENF 7-5-1 & UENF 7-9-1 & Parent & UENF 7-9-1 & UENF 7-3-1 & Top Seed & Top Seed \\
\hline 12th & Parent & Feltrin & UENF 14-3-3 & Parent & Top Seed & UENF 9-24-12 & UENF 15-23-4 \\
\hline 13th & UENF 7-9-1 & Parent & UENF 7-9-1 & UENF 14-6-3 & UENF 9-24-12 & UENF 7-3-1 & Feltrin \\
\hline 14th & UENF 14-4-3 & Top Seed & UENF 7-4-1 & Feltrin & UENF 7-4-1 & UENF 7-4-1 & UENF 9-24-12 \\
\hline 15th & UENF 14-3-3 & UENF 7-6-1 & Feltrin & Top Seed & UENF $15-23-4$ & UENF 14-4-3 & UENF 7-4-1 \\
\hline 16th & Feltrin & UENF 15-23-4 & UENF 14-6-3 & UENF 14-4-3 & UENF 14-4-3 & UENF $15-23-4$ & UENF 14-6-3 \\
\hline 17 th & UENF 7-6-1 & UENF 7-10-1 & UENF 14-4-3 & UENF 15-23-4 & UENF 14-6-3 & UENF 14-6-3 & UENF 14-4-3 \\
\hline
\end{tabular}

studies by Miranda et al. (1997) with common beans, Oliveira et al. (2002) with sorghum, Vicente et al. (2004) with soybeans, Cargnelutti Filho et al. (2007) with corn, and Vilela et al. (2011) with bean pods.

However, the analysis of the performance of the strains in each environment showed that the UENF 7-10-1 strain was the most unstable strain in the best environment (Bom Jesus do Itabapoana - RJ, 2011), which corroborates the statement of Vilela et al. (2011), that this method indicates the strains that are poorly adapted to favorable environments.

The methodology of Plaisted and Peterson (1959) indicated the following strains as the most stable genotypes: UENF 9-24-2, UENF 7-12-1, UENF 7-4-1, and UENF 14-6-3. All of these, with the exception of UENF 7-12-1, presented average productivity below the general average. Furthermore, the UENF 14-6-3 strain obtained the worst overall average.

When the ranking of Kang and Phan (1991) was applied to the method of Yates and Cochran (1938), it highlighted the UENF 7-10-1, UENF 7-20-1 and UENF 7-14-1 strains, which achieved the first, fifth and seventh positions, respectively, for PY. On the other hand, the 3 most stable strains indicated by the Kang and Phan (1991) algorithm applied to the method of Plaisted and Peterson (1959) were UENF 7-12-1, UENF 7-5-1 and UENF 7-20-1. They were ranked fourth, third and fifth positions, respectively, for PY.

The Lin and Binns (1988) method ranked the most productive materials as the most stable (UENF 7-10-1, UENF 7-6-1 and UENF 7-5-1). However, their genetic percentages for interaction were $36.72,60.03$ and $80.88 \%$, respectively. The UENF 7-20-1 genotype stood out, as it achieved the fourth lowest Pi, the fifth highest yield and $97.29 \%$ genetic drift.

Bom Jesus do Itabapoana - RJ, 2010 (environment 1), and Bom Jesus do Itabapoana - RJ, 2011 (environment 2) presented positive indices and were considered favorable in this study. Environment 2 prevailed, as it obtained the highest averages compared to the other environments. 
When only the favorable environments were considered, the UENF 7-6-1 strain stood out for obtaining yield equal to $34.79 \mathrm{t} / \mathrm{ha}$ (environment 1) and $46.90 \mathrm{t} / \mathrm{ha}$ (environment 2). However, in the unfavorable environment, this strain produced only $29.96 \mathrm{t} / \mathrm{ha}$. Therefore, the UENF 7-6-1 genotype was specifically recommended for cultivation in Bom Jesus do Itapaboana - RJ, and is responsive to environmental improvement.

The UENF 7-10-1, UENF 7-14-1 and UENF 7-20-1 strains stood out for the unfavorable environment, as they achieved the 3 highest averages for PY in this environment, namely, $38.69,37.22$ and $36.34 \mathrm{t} / \mathrm{ha}$, respectively. It is noteworthy that these 3 strains were also considered the most stable by the method of Kang and Phan (1991) when applied to the traditional method (1938).

The UENF 7-12-1 strain was ranked at the fourth position in both favorable and unfavorable environments, with a PY average of $35.53 \mathrm{t} / \mathrm{ha}, 40.79 \mathrm{t} / \mathrm{ha}$ and $30.83 \mathrm{t} / \mathrm{ha}$ (environments 1,2 and 3, respectively). Therefore, this strain is a good alternative for both low and high technology conditions, since it is a stable and responsive genotype (with wide adaptation).

However, the following strains stood out: UENF 7-5-1, UENF 7-10-1, UENF 7-101, UENF 7-14-1, and UENF 7-20-1, since they received the best combined indications by the various methods used in this study (Table 4). By the complementary information obtained by different methods, the strain UENF 7-5-1 was indicated for favorable environments, i.e., Bom Jesus do Itabapoana (2010 and 2011), the UENF 7-10-1, UENF 7-14-1 and UENF 7-20-1 strains were indicated for the unfavorable environment (Cambuci) and the UENF 7-12-1 strain was indicated for both.

Table 4. Ranking of the three best strains by the Traditional method (1938), Plaisted and Peterson (1959), Kang and Phan (1991), Lin and Binns (1988) and Lin and Binns (1988) adapted by Carneiro (1998) for productivity of pod yelds (PY).

\begin{tabular}{|c|c|c|c|c|c|c|c|c|c|c|c|c|c|c|c|c|c|}
\hline \multirow[t]{2}{*}{ Methods } & \multicolumn{17}{|c|}{ Strains } \\
\hline & 1 & 2 & 3 & 4 & 5 & 6 & 7 & 8 & 9 & 10 & 11 & 12 & 13 & 14 & 15 & 16 & 17 \\
\hline Traditional (1938) & - & - & - & $2^{\circ}$ & - & - & - & - & $1^{\circ}$ & - & 30 & - & - & - & - & - & - \\
\hline Plaisted and Peterson (1959) & - & - & - & - & $3^{\circ}$ & - & - & - & - & $2^{\circ}$ & - & - & $1^{\circ}$ & - & - & - & - \\
\hline Kang and Phan (1991)/Traditional (1938) & - & - & - & - & - & - & - & - & $1^{\circ}$ & - & $3^{\circ}$ & $2^{\circ}$ & - & - & - & - & - \\
\hline Kang and Phan (1991)/Plaisted and Peterson (1959) & - & - & - & - & - & $2^{\circ}$ & - & - & - & $1^{\circ}$ & - & $3^{\circ}$ & - & - & - & - & - \\
\hline Kang and Phan (1991)/Wricke (1965) & - & - & - & - & - & $2^{\circ}$ & - & - & - & $1^{\circ}$ & - & $\overline{3^{\circ}}$ & - & - & - & - & - \\
\hline Lin and Binns $\left(\mathrm{P}_{\mathrm{ig}}\right)$ & - & - & - & - & - & $3^{\circ}$ & $2^{\circ}$ & - & $1^{\circ}$ & - & - & - & - & - & - & - & - \\
\hline Lin and Binns $\left(\mathrm{P}_{\mathrm{if}}\right)$ & - & - & - & - & - & $\overline{2^{\circ}}$ & $1^{\circ}$ & - & - & - & - & - & - & $3^{\circ}$ & - & - & - \\
\hline Lin and Binns $\left(\mathrm{P}_{\mathrm{id}}\right)$ & - & - & - & - & - & - & - & - & $1^{\circ}$ & - & $2^{\circ}$ & $3^{\circ}$ & - & - & - & - & - \\
\hline General average (PY) & - & - & - & - & - & $3^{\circ}$ & $2^{\circ}$ & - & $1^{\circ}$ & - & - & - & - & - & - & - & - \\
\hline
\end{tabular}

$\mathrm{P}_{\mathrm{ig}}=$ general stability index $(\mathrm{Pi}) ; \mathrm{P}_{\mathrm{if}}=\mathrm{Pi}$ favorable environment; $\mathrm{P}_{\mathrm{id}}=$ Pi unfavorable environment. $1=$ Parent (UUENF 1445); 2 = Feltrin; $3=$ Top Seed Blue Line; $4=$ UENF 7-3-1; $5=$ UENF 7-4-1; $6=$ UENF 7-5-1; $7=$ UENF 7-6-1; 8 = UENF 7-9-1; $9=$ UENF 7-10-1; $10=$ UENF 7-12-1; $11=$ UENF 7-14-1; $12=$ UENF 7-20-1; $13=$ UENF 9-24-12; 14 = UENF 14-3-3; 15 = UENF 14-4-3; 16 = UENF 14-6-3; 17 = UENF 15-23-4.

\section{ACKNOWLEDGMENTS}

The authors thank Conselho Nacional de Desenvolvimento Científico e Tecnológico (CNPq) and Fundação Carlos Chagas Filho de Amparo à Pesquisa do Estado do Rio de Janeiro (FAPERJ) for the scholarships that were granted and their assistance. 
Recommendations for snap beans

\section{REFERENCES}

Allard RW (1971). Princípios do Melhoramento Genético de Plantas. Edgard Blucher, São Paulo.

Backes RL, Elias HT, Hemp S and Nicknich W (2005). Adaptabilidade e estabilidade de genótipos de feijoeiro no Estado de Santa Catarina. Acta Sci. Agron. 27: 309-314.

Borges LC, Ferreira DF, Abreu AFB and Ramalho MAP (2000). Emprego de metodologias de avaliação da estabilidade fenotípica na cultura do feijoeiro (Phaseolus vulgaris L.). Rev. Ceres 47: 89-102.

Brasil (2012). Ministério da Agricultura, Pecuária e Abastecimento. Requisitos Mínimos para Determinação do Valor de Cultivo e Uso de feijão, para a Inscrição no Registro Nacional de Cultivares - RNC Anexo IV. Available at [http:// www.agricultura.gov.br/]. Accessed January 15, 2012.

Cargnelutti Filho A, Perecin D, Malheiros EB and Guadagnin JP (2007). Comparação de métodos de adaptabilidade e estabilidade relacionados à produtividade de grãos de cultivares de milho. Bragantia 66: 571-578.

Carneiro PCS (1998). Novas Metodologias de Análise da Adaptabilidade e Estabilidade de Comportamento. Doctoral thesis, Universidade Federal de Viçosa, Viçosa.

Cruz CD (2006). Programa Genes: Biometria. Editora UFV, Viçosa.

Cruz CD and Regazzi AJ (2001). Modelos Biométricos Aplicados ao Melhoramento Genético. $2^{\mathrm{a}}$ ed. UFV, Viçosa.

Falconer DS and Mackay TFC (1996). Introduction to Quantitative Genetics. 4th edn. Logman Group Limited, Endiburgh.

Farias FJC, Ramalho MAP, Carvalho LP, Moreira JAN, et al. (1997). Parâmetros de Parâmetros de estabilidade propostos por Lin e Binns (1988) comparados com o método da regressão. Pesq. Agropec. Bras. 32: 407-414.

Fehr WR (1987). Principle of Cultivar Development. Macmillan, New York.

Hallauer AR and Miranda Filho JB (1986). Quantitative Genetics in Maize Breeding. Iowa State University Press, Ames.

IBGE (2010). Instituto Brasileiro de Geografia e Estatística. IBGE Cidades. Available at [http://www.ibge.gov.br/ cidadesat/topwindow.htm?1]. Accessed January 20, 2012.

Kang MS and Phan HN (1991). Simultaneous selection for high yielding and stable crop genotypes. Agron. J. 83: 161-163.

Lin CS and Binns MR (1988). A superiority measure of cultivar performance for cultivar x location data. Can. J. Plant Sci. 68: 193-198.

Mauro AOD, Curcioli VB, Nóbrega JCM, Banzato DA, et al. (2000). Correlação entre medidas paramétricas e nãoparamétricas de estabilidade em soja. Pesq. Agropec. Bras. 35: 687-696.

Miranda GV, Vieira C, Cruz CD and Araújo GAA (1997). Comparação de quatro métodos de avaliação da estabilidade fenotípica de cultivares de feijão. Rev. Ceres 44: 627-638.

Murakami DM, Cardoso AA, Cruz CD and Bizão N (2004). Considerações sobre duas metodologias de análise de estabilidade e adaptabilidade. Ciênc. Rural 34: 71-78.

Oliveira JS, Ferreira RP, Cruz CD, Pereira AV, et al. (2002). Adaptabilidade e estabilidade em cultivares de sorgo. Rev. Bras. Zootec. 31: 883-889.

Plaisted RL and Peterson LC (1959). A technique for evaluating the ability of selection to yield consistency in different locations or seasons. Am. Potato J. 36: 381-385.

Prado EE, Himoroto DM, Godinho VPC, Utumi MM, et al. (2001). Adaptabilidade e estabilidade de cultivares de soja em cinco épocas de plantio no cerrado de Rondônia. Pesq. Agropec. Bras. 36: 625-635.

Rosse LN, Vencovsky R and Ferreira DF (2002). Comparação de métodos de regressão para avaliar a estabilidade fenotípica em cana-de-açúcar. Pesq. Agropec. Bras. 37: 25-32.

Scapim CA, Pacheco CAP, Amaral Júnior AT, Vieira RA, et al. (2010). Correlations between the stabitity and adaptability statistics of popcorn cultivars. Euphtytica 174: 209-218.

Silva WCJ and Duarte JB (2006). Métodos estatísticos para estudo de adaptabilidade e estabilidade fenotípica em soja. Pesq. Agropec. Bras. 41: 23-30.

Souza PM, Ponciano NJ, Mata HTC, Brito MN, et al. (2009). Padrão de desenvolvimento tecnológico dos municípios das regiões Norte e Noroeste do Rio de Janeiro. Rev. Econ. Sociol. Rural 47: 945-969.

Vicente D, Pinto RJB and Scapim CA (2004). Análise da adaptabilidade e estabilidade de linhagens elite de soja. Acta Sci. 26: 301-307.

Vilela FO, Amaral Júnior AT, Gonçalves LSA, Barbé TC, et al. (2011). Stability of $\mathrm{F}_{7.8}$ snap bean progênies in the Northern and Northwestern regions of Rio de Janeiro State. Hortic. Bras. 29: 84-90.

Yates F and Cochran WG (1938). The analysis of groups of experiments. J. Agric. Sci. 28: 556-580. 